\title{
Making a Noise - Making a Difference: Techno-Punk and Terra-ism
}

\author{
GRAHAM ST JOHN \\ UNIVERSITY OF QUEENSLAND
}

\begin{abstract}
This article charts the convergence of post-punk/post-settler logics in the techno-punk development in Australia. Exploring how punk would become implicated in the cultural politics of a settler society struggling for legitimacy, it maps the ground out of which Labrats sound system (and their hybrid outfit Combat Wombat) arose. It provides an entry to punk through an analysis of the concept of hardcore in the context of cultural mobilisations which, following more than two centuries of European colonisation, evince desires to make reparations and forge alliances with Indigenous people and landscape. To achieve this, the article traces the contours and investigates the implications of Sydney's techno-punk emergence (as seen in The Jellyheads, Non Bossy Posse, Vibe Tribe and Ohms not Bombs), tracking the mobile and media savvy exploits of 1990s DIY sound systems and techno terra-ists, aesthetes and activists adopting intimate and tactical media technologies, committing to independent and decentralised EDM creativity, and implicated in a movement for legitimate presence.
\end{abstract}

\section{Keywords}

techno, anarcho-punk, hardcore, sound systems, postcolonialism, Sydney techno-punk scene

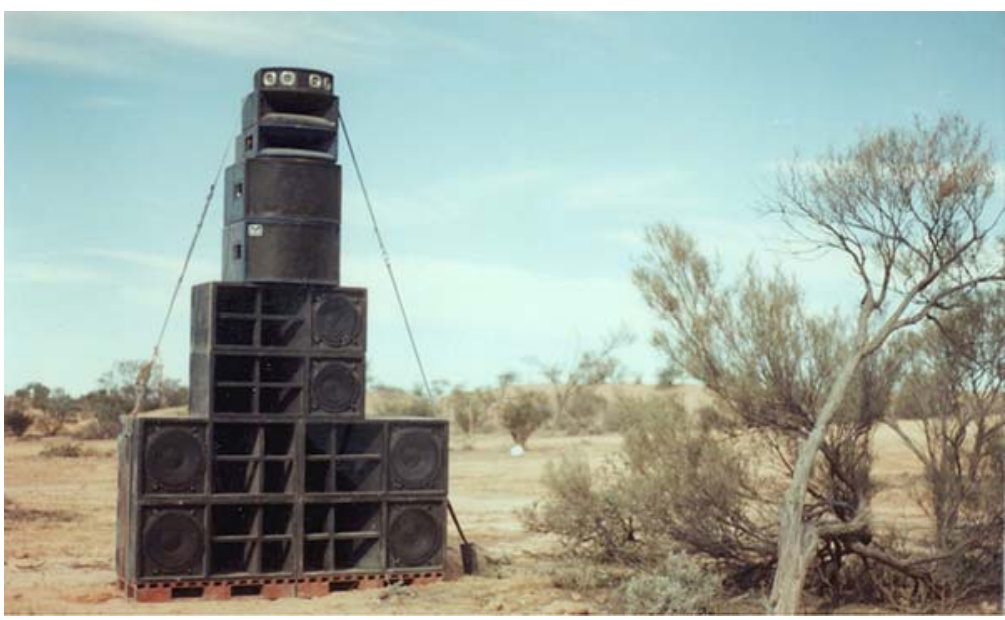

Figure 1: Outback Stack. Photo by Pete Strong 


\section{Making a Difference}

"Why do they keep calling our generation, generation $\mathrm{x}$, when actually we're generation y?... Why? Because we're the one's asking the questions". Reproduced in Sydney zine Sporadical (2001: 21), Monkey Marc's statement underscored an inquisitive and compassionate momentum building within an alternative milieu in late 1990s Australia. It registered a desire to find solutions to the rise of market fundamentalism and the persistence of colonisation - a desire to "make a difference". 'Spurred by ecological imperatives and responding to the plight of Indigenous custodians, "Monkey" Marc Peckham co-founded alternative energy and multimedia sound system Labrats. While displaying contempt for the spectacular self-obsessions of a "cliché repressed species stuck in the $80 \mathrm{~s}^{\prime 2}$, the Labrats intervention possessed the hallmarks of the directed anger and productive independence characteristic of post-punk anarchism. Yet, here, the motivation was less class war than ecology and justice for Aboriginal people. According to a post-punk/post-settler logic, the spectacular contempt for authority displayed by forebears was eclipsed by deference to that felt to constitute the "proper authority": the country and its traditional custodians. This independent countercolonial trajectory should be understood within the context of postcolonising gestures and legitimacy practices mounting through the 1990s, the so-called "Decade of Reconciliation", and subsequently. In response to anxieties over settler-complicity in a wounded country, and ignited by the Howard Government's apparent contempt for Indigenous Australia, a compendium of redressive actions would emerge. But while Landcare initiatives, the performances of "sorry people" (Gooder and Jacobs 2000), and the Sydney Olympics Opening Ceremony (Cohen et al. 2008) illustrated official responses to the identity crisis, independent, empathetic and intercultural initiatives to "care" and "fight" for country were taking place in which indigenous and indigenised authorities were compelling nascent custodial sensibilities, ecological sensitivities and redemptive strategies (see St John 2000, 2001a, 2006).

Labrats would strike a curious pose in this climate. Elements of a "loose assemblage of guerrilla militias" emerging in the late 1990s, they illustrated Dylan Clark's (2003: 234) observation that "punk can be hidden even to itself". In exploring how punk would become implicated in the cultural politics of a settler society struggling towards legitimacy, this article maps the ground out of which Labrats (and their hybrid outfit Combat Wombat) arose. It thus provides an entry to punk through an analysis of the concept of "hardcore" in the context of cultural mobilisations which, following more than two centuries of European colonisation, evince desires to make reparations and forge alliances with Indigenous people and landscape. To achieve this, I chart the contours and implications of Sydney's ${ }^{3}$ techno-punk emergence. Exploring Sydney's Jellyheads and the Vibe Tribe, and tracking the mobile and media savvy exploits of 1990s DIY sound systems and techno terra-ists emerging in their wake (from Non Bossy Posse to Ohms not Bombs and the Labrats), I provide illustration of the counter-colonial trajectory of punk.

\section{Hardcore: Intimate and Tactical}

I begin this essay, then, with a discussion of hardcore. It should be understood at the outset that the concept of hardcore under scrutiny is not exhausted by a musical aesthetic dubbed "hardcore" - typically, and originally, an aesthetic belonging to North American and UK hardcore punk rock scenes. Moreover, the essay is less an investiga- 
tion of "hardcore" music than of climates of response to conditions of adversity, inequality and injustice that contextualise the embrace of, and identification with, this term. The commitment to survival strategies necessitated by material disadvantage, inequality and discrimination, and the resistance to such crises, hold much in common. While perhaps respectively characterising futility and hope, these dispositions equally disclose a "street wiseness", rawness, anger, struggle. And it seems that to be "hardcore" is to be empirically proximate to such socioeconomic pressures - inheriting the prospect of having "no future" or undertaking to "reclaim the future" from those who would have it clear-felled. In the 1970s, researchers at Birmingham's Centre for Contemporary and Cultural Studies began to circumscribe the, until then, largely neglected cultural character of such responses, finding that within post-war working class youth subcultures, the solutions to such exigencies would be mediated increasingly and dramatically through their translations and appropriations of popular culture through style. An angry aesthetic - hostile, disruptive, excessive and ironic - was particularly evident in punk. To perform contempt for private property and public propriety - especially through a dissonant music with screaming vocals - was demonstrative of an authentic, or hardcore, punk sensibility: it expressed a hard edge, the raw immediacy of the street. With punk's commodification and a subsequent resurgence of anarchist DIY networks, ${ }^{4}$ anarcho-punk and direct action would come to hold particular authenticity since such were "harder" (and thus "truer") than a merely stylistic, and thus commodifiable, punk sensibility.

While I make no pretence at capturing the essence of punk, I have to assume that those who identify as/with punk in large part believe that they are approximating its truth by performing, promoting, living its assumed character. Thus "hardcore" becomes a most curious label, the unraveling of which facilitates understanding of punk developments. While my description of "hardcore" encompasses that understood as a continuous punk practice, this conceptual development allows for an understanding of its affinity and contiguity with other subcultural and music scenes (preand post-punk), some of which, are felt to have been, at least initially, irreconcilable to punk. In particular, I am thinking of electronic dance music. Thus, my discussion is less motivated to explicate punk's hardcore scene/s and music/s than it is to comprehend the affinity between punk and EDM, whose cultures - from disco to jungle, and from hip hop to psytrance - illustrate "hardcore" dispositions and "vibes" (see St John 2009). While analysis of "hardcore" music is not critical to this investigation, Simon Reynolds pronouncements on what he calls the "hardcore continuum" (HCC) within UK EDM (not to be confused with the European "hardcore" tradition of "gabba", which has evolved into "terrorcore"), are important.5 According to Reynolds, from breakbeat hardcore (or "ardcore") to jungle and UK garage, to grime, dubstep and bassline, a continuum can be observed in which pirate radio, dub plates, MCing, multiculturalism, populations of enthusiasts not exclusively centered in London, and a continuity of sound and attitude (in which he includes a "cheekiness", blissful female vocals, and stylistic faithlessness) are crucial. Between 1990 and 1993, UK "hardcore" was rife and diverse. Reynolds (1998: 96-7) has described how the term referred "by turns to the Northern bleep-and-bass sound of Warp and Unique 3, to the hip-house and ragga-techno sounds of the Shut Up and Dance label, to the anthemic pop-rave of acts like N-Joi, and Shades of Rhythm, to Belgian and German brutalist tekno, and, finally, to the breakbeat-driven furore of hardcore jungle". He also notes how all such music supplied "the rave audience's demand for a soundtrack to going mental and getting fucked up" (1998: xvii), a process that he has pursued via a dystopian pharma- 
cological "come down" narrative. But, this music, he claims, has been the British "equivalent to hip hop and our equivalent to reggae... a musical system that endures while evolving at an insane rate". In his distinctive ebullience, Reynolds offers insight on the continuity:

the basic coordinates of hardcore in [the] defining year of 1992 are a four way collision of hip hop and techno, reggae and house... It's like a multiple pile-up at a crossroads. And the BIG BANG releases this surge of energy: you have this crazy-fast evolution of hardcore into jungle, the development of breakbeat science and bass science - the breaks get sped up, edited, processed, fantastically complex yet jagged yet groovy rhythms - the bass gets more strange and peculiar, molded and gloopy, yet also punishing, and yet also heavy in a rootical sense, the dub reggae sense, there's a skanking feel in there too.

What I wish to draw attention to here is the importance of continuity at the very heart of "hardcore", as a concept. In my view, there are two, sometimes conflicting and other times mutual, propensities from which the concept hardcore appears to derive its vitality, and in which it expresses continuity (in punk, EDM and other scenes). On the one hand, it appears that a hardcore scene is characterised by secrecy, obscurity and an almost cultic disposition. Events are communicated by word-of-mouth and on subthe flyers distributed through local channels. Efforts to maintain an independent "tribal" identity, an "empathetic sociality" (Maffesoli 1996: 11), through commitment to genre and to an almost universal envelope-pushing esoterica, evidence a refusal, an aloofness, an invisibility thought to secure scenes from the long entwined arms of state administrations and corporate entertainment industries. Responding to that which CCCS researcher and author of Subculture: The Meaning of Style, Dick Hebdige, identified as (inevitable) incorporation, punks engage in "a refusal of meaning, a blankness which resists any complete and final decoding” (Beezer 1992: 114). Such illegibility and incomprehensibility may (re)affirm an "underground centrality" that is guardedly unco-opted.

On the other hand, hardcore evokes a desire to "step up", "get the message out", be comprehended. Employing direct action techniques and repurposing media technologies to broadcast the "truth", it generates often quite public spectacles in the service of causes other than simply its own reproduction. And in its desire to transgress boundaries, to reach a critical mass, it demonstrates that "we are everywhere". So while the former tendency finds refuge within the guarded boundaries of its own traditions, amidst a resurgent DIY politics, the latter seeks to open its borders, clarify an ethos and make a spectacle - of itself and the corporate and colonial structures against which it fashions its cultural resistance.

These insular and activist propensities may characterise different punk scenes. In annual defiance of Melbourne's largest sporting event, the Punk Pub Crawl during the Australian Football League's Grand Final Day represents a critical moment of selfvalidation and sociality for that city's scenes (Lentini 2002: 191). In Tempe, Arizona, economically marginal gutter punks, skate punks and others disrupt "the aggressive regulation of open public interaction" affected by community ordinances and unsettle the sanitised "landscapes of suspicion and exclusion" consequent to the Disneyfication of the American city (Ferrell 2001: 12, 13). As such, "their worlds throw uncertainty up against predictability and order, offer moments of autonomous pleasure in the face of orchestrated entertainment, celebrate a sort of shambling marginality in counterpoint to an emerging economy and aesthetics of middle-class life" (Ferrell 2001: 87). 
Affecting a confronting aesthetic that developed global appeal since the emergence of punk in the late 1970s, a refusal of consumer capital's disciplined body is expressed via facial tattoos and piercings, outrageous hedonism and a decadent warming towards the apocalypse. By contrast with nihilists identifying with an exclusively shocking and anti-authoritarian aesthetic which would itself be subject to consumerist normalization, DIY milieus exemplified by the anarcho-punk band Crass and the free food "distro" activists Food Not Bombs would demonstrate commitment towards voluntarism, social justice, human rights and ecological sustainability (McKay 1998). ${ }^{7}$ Implying an historical trajectory, Dylan Clark (2003: 233) argues that with post-punk "the performance of anarchy" found in early punk would be replaced by "the practice of anarchism". While I feel it is useful to identify these hardcore dispositions, they are often difficult to isolate in practice. As Pete Lentini (2002: 188) suggests, punk signifies a "politics of difference" where hegemonic dissidents pursue new sites within which to develop networks of "cultural citizenship". In this sense, acts of refusal, defiant rituals and sites of sociality - bands, squats, boycotts, body modifications and punk picnics - are contexts for the performance of counter-narratives.

In punk, as with other spectacular subcultures, style, appearance and performance are employed as media of identification and as expressions of difference. Yet, deployed to expose and intervene in State and corporate affairs, these aesthetics, this noise, assists in rupturing existing sites, institutions and corporations, to create an opening to heterogeneity, to generate dialogue with others, to make a difference. DIY milieus adopt, share and repurpose media to communicate their difference amongst themselves (to reaffirm marginal identity) and to others (to alter social and political circumstance). ${ }^{8}$ In accordance with this, DIY adherents became adepts of a range of media used in intimate and tactical endeavors. While that which influential anarcholibertarian philosopher Hakim Bey called "intimate media"y could enable a fluid and sensuous neo-tribal present - could make, or remake, the social - this same media is potentially provocative and tactical. It could be deployed to make a spectacle - of the State, militarism, consumer capitalism, the nuclear family, patriarchy, racism, etc. And punk sociality (on the street, at the venue, in the collective), while orgiastic in the Maffesolian sense (1993) of a fluid and sensuous neo-tribalism offering its fullest expression in the climactic festal, tends also towards the organic. Decentralised structures encouraging mutual responsibility and consensual outcomes, anarcho-punk "temporary autonomous zones" (or TAZ: Bey 1991a) nurture the kind of immediate experiments-of-the-self Bey embraced as "radical conviviality". ${ }^{10}$ Furthermore, the orgiastic-organicism of the TAZ can be a context for intervention. Contextualising reclamations, direct action and culture jamming (from Reclaim the Streets to J18 and other "protestivals", see Figure 2), ${ }^{11}$ a temporary "orgiasm" potentiates more enduring subversions.

Reclamational tactics, which Tim Jordan (2002: 26) claims "draw on the future to create the future", may be working examples of "future-presence" or "futures in the present". Paraphrasing the Preamble to the Constitution of the IWW, Jeff Shantz (1999: 60-61) suggests that such tactics "attempt to form the structure of the new world in the shell of the old". As such, these tactics evince the renewed popularity of anarchist and autonomist politics manifest in a vast network of collectives and in proglobal justice events and World Social Forums. Where punk heirs act out the future in the present, co-opting media to their own goals, they appear to be cognizant that "the ultimate authenticity lies in political action" (Clark 2003: 234) rather than in a preoccupation with unmarketable purity. 


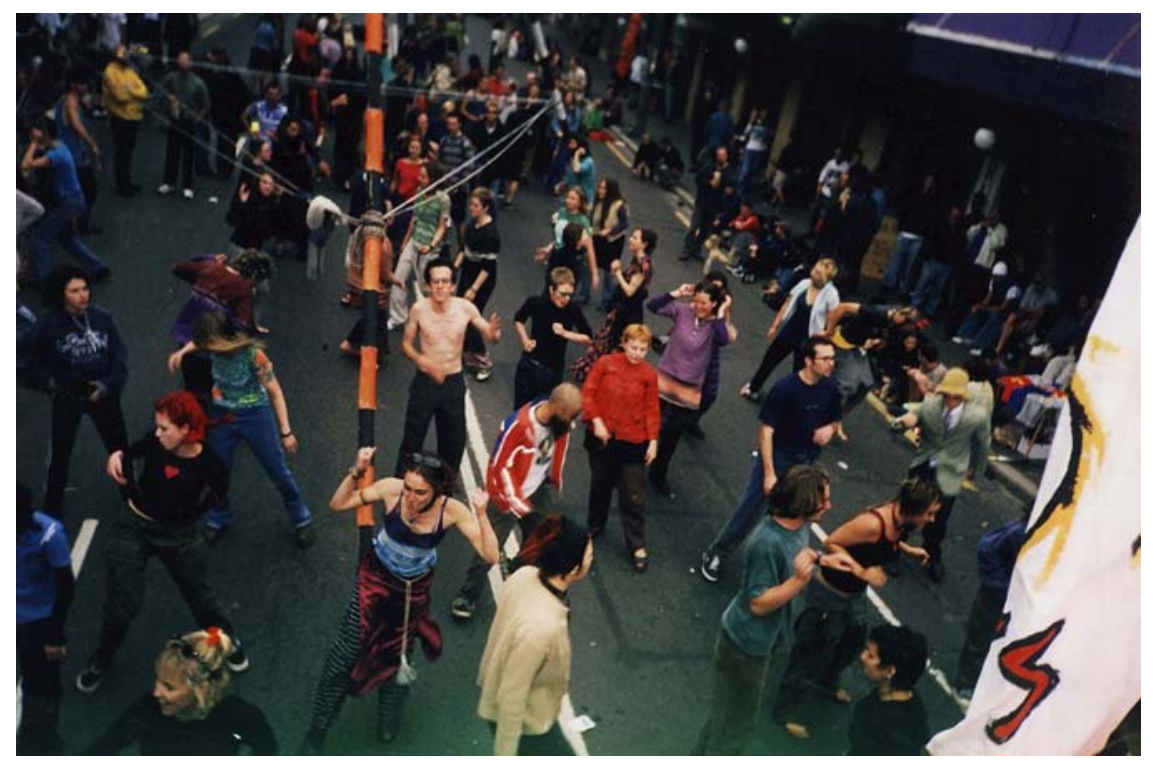

Figure 2: Reclaim the Streets, Newtown, Sydney, 1999. Photo by Pete Strong

\section{Knowing the Score: EDM and Tactical Dance}

In the early 1990 s, post-rave electronic dance music came to hold a strong bearing on punk. While punk's common response to rave - like rock's reaction to disco and house before it ${ }^{12}$ - was that it "sucked", as electronic dance music was adopted in the quest to realise the "future-presence", the sight, sound and experience of EDMC would become more appealing. From the late 1980s UK, a techno-cultural accretion incorporating electronic music, psychotropic lighting, chemical alterants and all night dancing possessed a libertarian sensibility integral to a rapidly escalating millenarianism. The techno-rave experience was recognised to possess greater potential than other popular music forms, especially rock, in the gathering carnival of resistance throughout the 1990s. Jeremy Gilbert noted that "whereas rock music corresponds more closely with representational politics", the immediacy of contemporary dance music made it ideal as a medium for direct-action - for direct democracy (1997, in Huq 2002: 93). Making manifest a "hidden future inside the present", the ecstatic intimacy of rave shares a "radical indeterminacy" (Jordan 2002: 46) with non-violent direct action - a condition of uncertainty powerful in its potential to unite disparate parties. A transgressive and decentralised "pleasure-politics" would thus be recruited from its secret nocturnal domains for causes external to itself. With the ekstasis (see Hemment 1996) of the early rave scene suited to the tactics of direct action, or more precisely, "direct theatre" (Schechner 1992: 104), tactical dance became implicated in anti-corporate globalisation protests and opposition to US aggression in the aftermath of 9-11.13

As intimated, there is considerable contiguity between the hardcores of punk and electronica (whether UK "ardkore" or European "tekno" sound system scenes), with an examination of these "cores" promising insights on global music cultures. Those identifying with "hardcore" electronica, like their punk predecessors (and contemporaries), appear to have been in possession of a "privileged knowledge" (see Fitzgerald 1998: 47) revealed by the popular phrase "ardkore, you know the score". Here, being hardcore means being committed to - knowing - the style (music, drugs, 
language, gestures, history, attitude), and being proximate to - knowing - the streets (social injustice, racism, discrimination, etc). As with punk, commitment to "ardkore" or "tekno" style was an expression of one's proximity to an authentic life. And, like hardcore punk, and with the assistance of the ever-alert corporate entertainment industry and its advertising arms, such style could be affected by those with little experience of, or concern for, poverty, racism or the environment. But by the mid 1990s, there were proponents of hardcore and other post-rave styles who were mobilising in response to ongoing social and political causes and effectively distinguishing themselves from those committed to a corporate defined and controlled rebellion.

EDM also afforded a new medium, a politics of production enabled by new accessible technologies. Through the acquisition of relatively inexpensive digital technology that facilitated the establishment of bedroom studios, pirate radio, fanzines, micro-labels etc, post-house dance musicians were enjoying the kind of decentralised anti-mainstream approaches unheard of in previous underground dance music cultures (Hesmondhalgh 1998: 237). And, in a disruption of the authorship categories of earlier popular music scenes, dance also represented an (often thwarted) attempt to collapse the passive spectator/genius performer role of rock and punk. Indeed its challenge to the music industry's "star system" (replicating such challenges made by countercultural and punk forebears) was regarded by early music press commentators as a distinctive feature of the genre: "There was a strong implication... that the star system represented fetishization of certain individuals, and dance music culture, like many youth music movements, was based on a celebration of collectivism" (Hesmondhalgh 1998: 239). Of course, this represented an ideal perspective contradicted by the emergence of the DJ as "star", who, as the artist in an arena of performance downstream from the western concert tradition, and most clearly apparent at mega-rave festivals, is separated from the audience. Also, as David Hesmondhalgh (1998: 246) further demonstrates, using their subsidiary record labels to "buy credibility" from independent labels, entertainment corporations like Polygram and EMI had "worked to assimilate as rapidly as possible the symbolic resonances attached to independent record production". Such offered nothing more than "pseudo-indification" challenging inflated claims of "democratisation".

From new analogue and digital audio technologies, bedroom studios and the dance party itself, electronic dance media constitutes a technical aesthetic harnessed by post-punk/post-rave actors not only in the interests of being different (making noise) - but in the effort to make a difference (make a noise). Throughout the 1990s, electronic media (along with computer mediated technologies) would enable cosmopolitan counter-tribes to mount a range of challenges in the reclamation of the global commons. In Australia, DIY techno-activism would enable counter-colonial mobilisations amidst a mounting crisis of legitimacy. Variously critical of the state and corporate greed, advocating indigenous justice, human rights and ecological sustainability, Australian post-punk culture would become fertile terrain for the development of a post-settler ethos. And it was a techno-punk convergence that would prove particularly momentous, a complex junction that can be grasped via a discussion of the production aesthetic of electronic music and the dance party (or doof).

\section{“Improtopia”: Sydney Techno-Punk}

By the late 1980 s, a cut $\&$ paste sensibility that had evolved in the visual arts though cubism, futurism, Dadaism and punk, in electronic music practice through dub plating 
and through noise art and digital recording, would be adapted by musicians adopting new equipment (e.g. digital samplers and synthesisers) and techniques (e.g. dubbing, the live mix, turntable techniques). In particular, samplers proved to be very useful devices/instruments through which to pirate and rewrite sonic artifacts. As was explained by two principal instigators of the Australian underground techno development, John Jacobs and Peter Strong (1995/96), in a production with diverse influences from punk to hip hop, "sounds themselves can be liberated". With Akai X7000s, a "lively bleep once held prisoner by an oppressive track is free to dance to a different beat. Evil lyrics of consumption, fear and greed can be detourned and mutated into statements of joyful resistance". ${ }^{14}$ Thus the unsolicited duplication and creative recombining of the sonic detritus of popular media - distinctive stamps of dub, hip hop, house and techno - would be performed to incite opposition and ignite alternatives. Strong (aka Morphism or Mashy P) had a name for this referential sonic bricolage, this audio-culture-jamming. "Agit-house" would form the basis of protest techno, which itself belongs to a lineage of musical improvisation involved in "the struggle for a new culture" (Balliger 1995: 14).

Agit-house was a product of a recognition made by musicians in early $1990 \mathrm{~s}$ Sydney that the liberationist messages expressed in their punk acts could be laid down relatively seamlessly with the assistance of samplers, TR808 drum machines, an amplifier and some good bass bins. Exploiting the means by which new audio technologies could effect cut \& paste techniques, appropriated and remixed for new purposes and amplified through a PA, punks were programming their dissent to a new rhythm. And since the rhythm was ideally seamless, as multiple artists played long live sets or beatmatched their tracks, bodies were propelled on and on. Thus, unlike punk, this would become a certifiable dance culture - one which, via the rave and with the assistance of MDMA - inherited the palpably non aggressive and non-heterosexualist legacies of house, garage and disco, and the kinesthetic maelstrom of a love-in. But if it was tactile and empathetic, it was also conducive to anarchism - and could remain so as long as a compulsion to bottle the experience and shift it for a tidy sum was kept in check. If this was punk, the exterior would become un-leathered and furrier, accoutrements fluoro and that which enhance the senses, and while alcohol remained present it was no longer dominant.

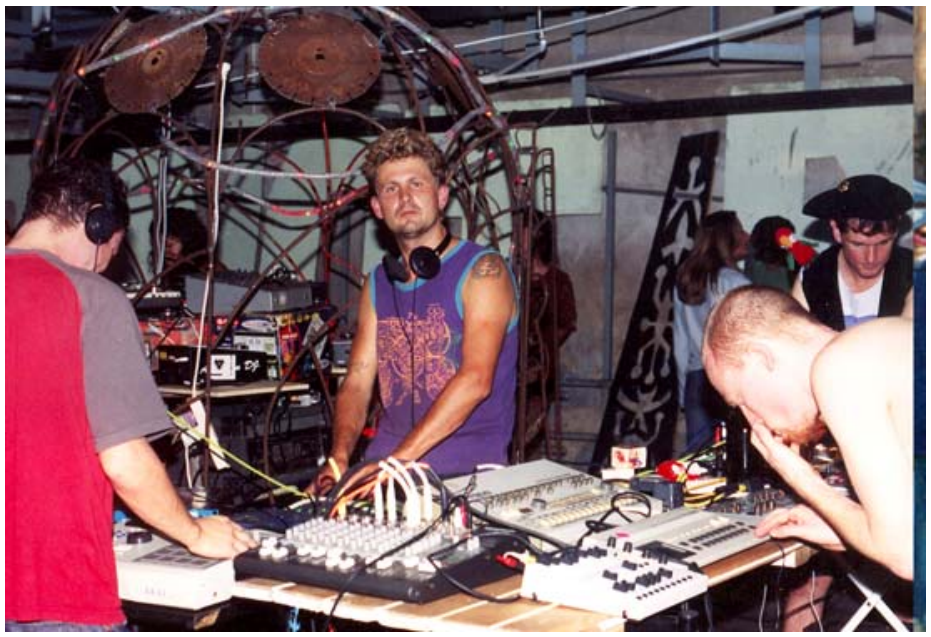

Figure 3: Non Bossy Posse at the Graffiti Hall of Fame. Photo by Peter Strong 
Amplifying issue-driven samples over breaks to rally the massive around a cause or to provide a soundtrack to public demonstrations, Non Bossy Posse (NBP) were probably the earliest exponents of Australian agit-house. They were a techno collective producing music in which voice samples like "people before profits", "old growth fuckin oath" and "we are everywhere" could be discerned over a driving squall of bleeps and breaks. ${ }^{15}$ Their performances were live, originally using finger synching techniques, and involved multiple musicians locking into a designated BPM, with each participant dropping freshly garnered or long favoured vocal samples into the jam. With multiple artists working simultaneously - rather than the solo DJ most common to electronic music performance - such constituted a true techno collective. Since these artists operated within an environment where experimentation and chance encounters with new audio technologies produced a reservoir of sounds and techniques shared by a growing techno underground, they approximated what Brian Eno identified as the collective "scenius" more than the "heroic auteur" of avant-garde traditions (Reynolds 1998: 127). While Reynolds was referring to techno's hardcore, NBPs derivations are diverse. Punk-traveler crossover band Crass (thought to have kick-started the UK anarcho-punk movement), Adrian Sherwood's Jamaican roots reggae On U Sound System, and UK techno, house, break beat collectives like DIY Sound System and Zero Gravity (Sporadical \# 1, Oct 1994; Murray 2001: 65) were inspirations. There was also substantial influence from message rap legends Public Enemy, who, like those associated with one of NBPs formative arrangements, Mahatma Propagandhi (MP), and fellow Sydney techno-artists Sub Bass Snarl, started out working on community radio shows. Activist beats were early recorded on NBP's tape Saboteurs of the Big Daddy Mind Fuck (1993). Adopting and repurposing increasingly accessible audio hardware, these activists instigated a tradition of promoting local political issues in the context of cutting edge music performances. Sampling the commentary of political leaders and activists from news reports, advertisements and sites of conflict, and mixing these with preprogrammed rhythms, they would provide an "alternative newscast" (Daly 1999: 9). These "freebooting sonic agitators" amplified issues of concern like police brutality, the arms trade, the drug war, indigenous justice, forest mismanagement, union matters and uranium mining. And with the assistance of experimental analogue video performance group Subvertigo (formed in 1992 by John Jacobs), activist filmic montage would accompany the sonic manifesto, such that the idea of "dance parties as multimedia political platforms" was born. ${ }^{16}$

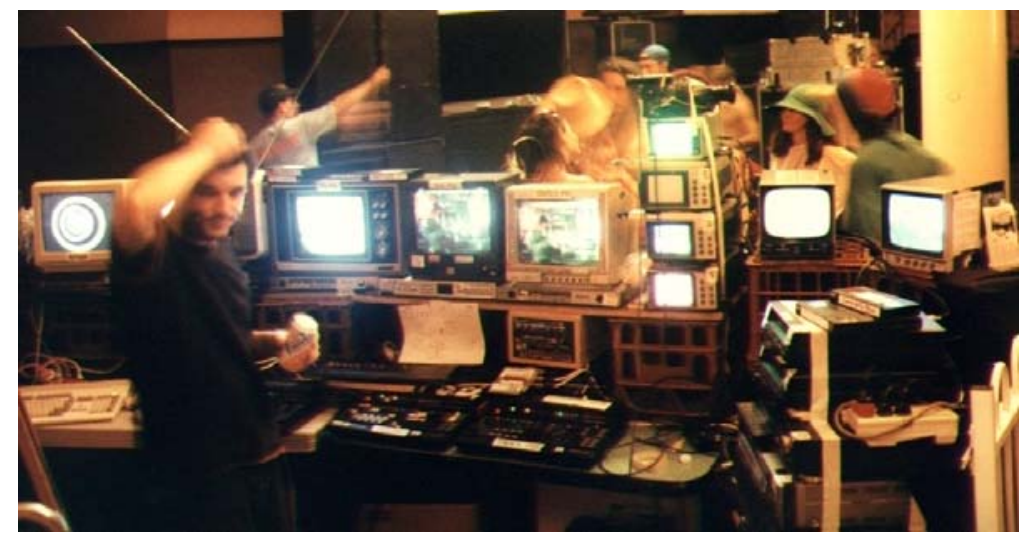

Figure 4: Subvertigo. Photo by John Jacobs 
Non Bossy Posse was formed in the Spring of 1992 by members of Sydney bands Mahatma Propagandhi (electronic/instrumental) and the Fred Nihilists (anarcho pop punk), who were regulars at live gigs in Newtown and Redfern, and were associated with the Jellyheads anarcho-punk collective. Forming in late 1989, the Jellyheads turned out to be one of Australia's most progressive punk developments. Motivated by "the idea of taking back control of our music, our lifestyle and our lives" (Jellyheads Blurb \# 6 April 1992), the Jellyheads "alternative venue project" drew inspiration from international initiatives like North Berkeley's 924 Gilman Street Project (aka the "Alternative Music Foundation”) (see Edge 2004), Belfast's Warzone Collective, and others with whom they shared a commitment to decision making through consensus and "a desire to create a cultural space free from sexism, racism and homophobia". ${ }^{17}$ Members were closely associated with local collectives and co-ops like Redfern's Black Rose Anarchist Bookshop, Alfalfa House Food Cooperative, and Radio Skid Row. ${ }^{18}$ The collective held numerous fundraising gigs, video nights and feasts to generate funds for a community PA (acquired in September 1992). ${ }^{19}$ Punk bands like Frenzal Rhomb and Nitocris would play there, but it was bands such as Fred Nihilist, Tutti Parze, Subliminal Pressure, Repeat Offenders and Deviant Kickback which were instrumental in raising funds to seed and maintain the Jellyheads initiative, and who themselves drew inspiration from the likes of Crass, Conflict, Chumbawamba and other UK anarchist punk bands raising funds for progressive causes. In some cases reluctantly, the Jellyheads were also receptive to developments within EDM, and came to host regular dance parties. Grant Focus regards the first such event, Jellignite, held at Regent St Hotel Redfern on February 20 1992, as one of the earliest moments in a punk-techno convergence:

\begin{abstract}
There was punks and doofers and Oxford Street gay crew and Chippo queer crew. There were punk/industrial DJs as well as electro stuff. Mohatma Propagandhi played and did a set with percussion and a sampler set up all over the dance floor so the crowd could also make the music with us. It was fun till the outdoor pool collapsed and we all got booted out!
\end{abstract}

These rapprochements continued and would trigger novel experiments. On May 16 1992, the "Propagandi Sound System" played at a celebration of the LA Uprising, Act Your Rage, in the newly occupied Jellyheads warehouse in Chippendale. This and other events at the time were contextualising something of a transition from band to sound system. According to "radical technician" and idea jockey John Jacobs, "we were a bunch of folks being acted on by contemporary cultural forces. We were using the tools at hand to put out a message in what we saw as the most effective and fun way". Like forebears who railed against the "star system" of late 1960s and early 1970s rock music, in a musical rebellion of simplification, amateurism and noise, Mahatma Propagandhi were also collectivising the performance - in their case not just through their aversion to rock, but in their objection to the idea of "the band" itself. ${ }^{20}$ For Jacobs, the band model was outmoded, possessing "limited active roles and outputs". By contrast:

the sound system model sat so much more comfortably with our way of working Jellyheads as a non-hierarchical collective. It had the flexibility to include more active participants in the co-creation of cultural situations including bringing the spectators (audience) into the creative loop. And had a more morphable output that was easily able to be scaled in intensity and duration to suit ad-hoc community gatherings? ${ }^{21}$ 


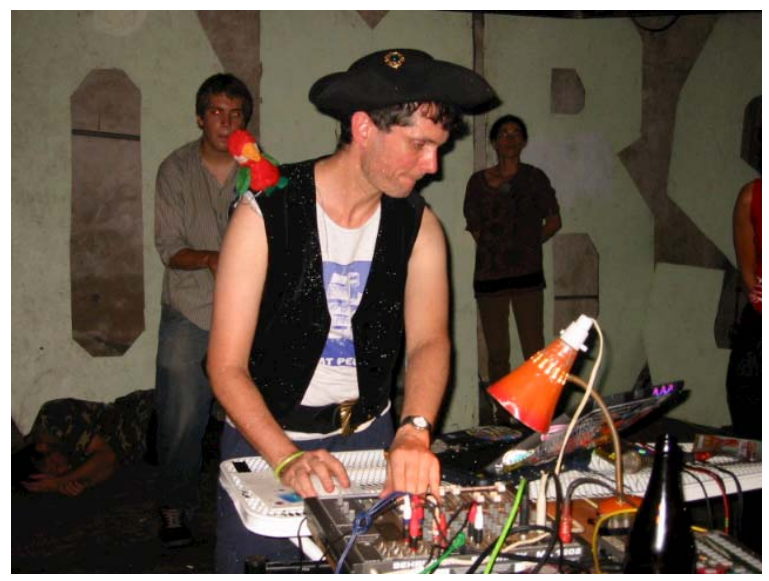

Figure 5: John Jacobs. Photo by Dan

Seeking to take music "back to the centre of social change action", Mahatma Propagandhi, and later Non Bossy Posse, would carry this sound system shift. Jacobs suggested that "if a utopia is defined as a no place, an imagined idyllic future society that doesn't (can't) exist, then that is hardly enough to aim for. We can live in Improtopia right now". Thus the impromptu and immediate sociality favored by anarchists would be consistent with, and even modulated by, new approaches to musical production. And while such an aesthetic insurrection had parallels with the first wave of Detroit techno artists who likened themselves to "techno-rebels" (after Toffler, see Sicko 1999), MP and NBP saw new audio-visual technologies adopted in accordance with organic anarchist principles. Reflective of a cut \& paste sensibility running through surrealism, jazz, beat art, punk and 1990 culture jamming, Jacobs holds a proactive aesthetic: "Remix reality. Work with what ever social elements are to hand. Listen or be sensitive to what is going on around you and start jamming with it. Add a little bit of your song to push the good parts of life's melody or rhythm along. Surprise your self and others every now and then with some dissonance or break beat".22

While this period (1990-1993) saw a transition from acoustic punk rock to the seamless aesthetic of live techno mixed by DJs, the new aesthetic was not adopted without opposition. As Strong recalls, the music was "mistrusted by some of the punk contingent". Reactions to early Sydney park events saw Graffiti in the park: "Kill Non Bossy Raver Scum, Techno = Disco" (Strong 2001: 73). Grant Focus explains how a "great tension" had mounted "between the punk and techno crowds", and that punks held a general distrust of the motives of those who many thought "were non-political middle class dickheads". The antipathy emerged "between the people who thought everyone should do everything for free and those who wanted to get paid or pay some people". Rave promoter Mike J of the early 1990s industrial club Cybernaut and later Virtual Bass (who also ran a rave called Primitive) earned "a lot of ill feeling" from punks. ${ }^{23}$ "The idea that the DJs would get paid but not the people who worked on the door or who cleaned up or did the recycling was not well received by most of us". As live rock and punk aficionados have long expressed contempt for "disc cultures" (Thornton 1995: 8) and the non-vocal textural prioritisations of "dance" music (Gilbert and Pearson 1999: 68-72), it is also likely that the distrust of techno reflected a perception that pre-recorded and non-vocal sound is not "raw", and is thus inauthentic. But anarcho-techno artists would demonstrate that their sonic assemblage was raw, 
vocal and authentic. While many punks, recounts Jacobs, regarded techno as "a middle class dance floor distraction", dismissed it as "mindless drug music", ${ }^{4}$ and/or, I would imagine, object to its presumed inauthenticity, NBP and their immediate precedents exploited the creative potential of new recording technologies to facilitate radical dance floors. This was achieved in the sense that their work illustrated plunderphonic artist John Oswald's assertion that "recorded sound is always raw - even when it is cooked" (Cutler 1995: 68), ${ }^{25}$ and that, employing vocal samples with or without irony, their sampladelic sensibility was indeed "vocal". Furthermore, they retained their noncommercial anarchist principles. According to Jacobs:

There were plenty of other people doing rave parties in Sydney. From the RAT parties in Marrickville to the gay parties at the Hordern. It was all illegal. But we were anarchists first and artists second. With us there was no one dude with a mobile - we were about people sitting in a circle and trying to do consensus decision-making. Putting the politics up front. When we sat down with our community to organise a gig, we were doing it as a political action first and art second (in Murray 2001: 66).

\section{Party-Machine: Vibe Tribe}

When the likes of the Propagandhi Sound System amplified punk's liberationist message under the roof of acid house, a bridge was said to have been built "from fullon punk power to more Balearic rhythms and dance grooves" (Strong 2001: 73). While the Jellyheads folded in early 1993 after the South Sydney Council placed an injunction on their fortnightly (and unlicensed) acid techno parties (Wobble), 26 "dissonance and breakbeat" would sound in the parks and repeat off the walls of St Peters and Newtown. Audio-bombers Non Bossy Posse would create the sonic graffiti for Circus Vibe Tribe, a party machine that virtually rose from the ashes of Jellyheads. Like the Jellyheads, Vibe Tribe were opposed to the commercial exploitation of electronic music and the privatisation of inner city space. The collective attracted alternative thinking people from far and wide. There were queer-anarchists disenchanted with the Sydney gay scene's commercial directions. A psychedelic trance aesthetic would circulate following Kol Dimond (Fatty Acidz) and Jeh Kaelin's (formerly drummer for the Fred Nihilists and later DJ JackieOnnasid) inspirational visit to Goa in 1990. Present also were "bush punks" or "ferals" who, since the turn of the decade, had been committing to direct actions to save "old growth" forest (see St John 1999). Vibe Tribers knew "the score". They possessed a wide range of musical influences (including punk and hard techno, or, later, breakcore). Attitudinally their knowledge of local social and political issues may have been privileged but it was not exclusive: they wanted everyone else to "know the score" too. In the first edition of their zine Sporadical, Vibe Tribe identified themselves as "a non-hierarchical collective pooling skills and resources with the aim of promoting collectivism strengthening community unity and reclaiming space to live alternative culture" (Sporadical \# 1 Oct 1994). Using the community sound system purchased through Jellyheads fundraising, Vibe Tribe were committed to orchestrating free dance parties, non-hierarchical sites of radical conviviality. ${ }^{27}$ As they "Reclaimed the Beach" at Congwong Bay, La Perouse, and squatted empty warehouses, Vibe Tribe would "highlight the problem of diminishing useable public space" (Chan 1999: 68). And as they opposed transport developments, such as the M2 motorway in Carmegeddon (July 1995), they performed the groundwork for the rapid translation of the UK Reclaim the Streets phenomenon. Austra- 
lians had a name for dance events evincing the crosspollination of anarchistic (inclusive and co-operative) ecological (conscientious and disciplined), digital (looped and optimistic), and transgressive (playful and carnivalesque) sensibilities: "doofs" (see St John 2001b; Strong 2001: 72; Luckman 2003). Anarcho-liminal events "in which people of all races, sexualities and cultural backgrounds can come together", Vibe Tribe's free doofs in Sydney Park combined music, art, video, performance, circus skills and interactive installations (Strong 2001: 74). Their first party, A-May-Zing, on May Day 1993 in Sydney Park, saw "an anarchist picnic mutate into a full on free party allnighter" (Strong 2001: 74). Posters promoted the event as a "celebration of resistance" which involved Sub Bass Snarl, Gemma, Ming D and Non Bossy Posse. On that night, as Strong recalls: "a huge banner emblazoned with the words 'Fuck the Rave Hierarchy' was strung aloft”.

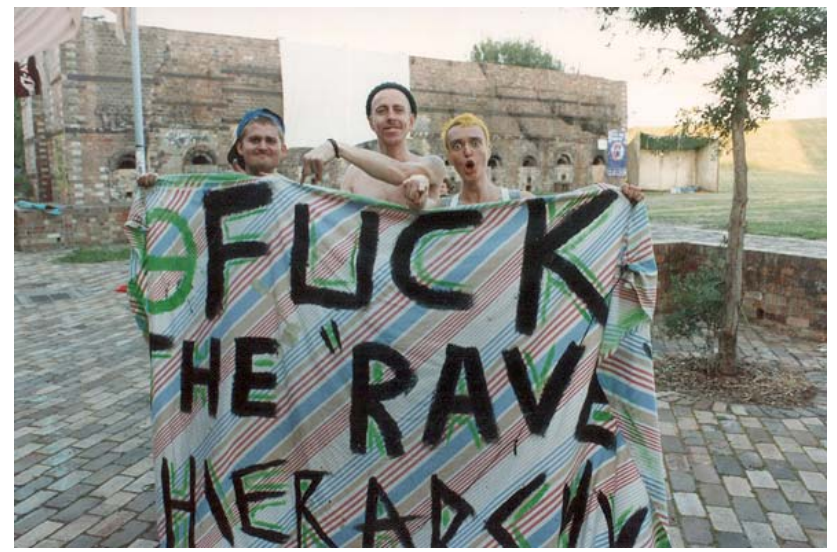

Figure 6: Fuck the Rave Hierarchy. Photo by Peter Strong

Jacobs recalls the period:

it was exciting and a lot of people were into it and very soon up to 1000 people were turning up at Sydney Park. And there was no venue, as in no walls or bouncers, so it had to be free. The bucket would go around so it was forced into being a political thing. Anyone that came along could feel that something special was happening. Ravers and homeys, punks and down and outs. It was a good mixed thing (from Murray 2001:31).

And anarchist principles would inform the entire process from performance through to eventual distribution with the Organarchy Sound Systems label set up to distribute material, some of which - following the widespread adoption of digital formats (such as MP3) - would later be made available as freeware. Establishing non-commercial autonomous spaces and employing de-centralized production and distribution technologies, according to Strong, "the spirit of punk was sustained and painted fluro as the Teckno seismic shift sent its tremors across Australian dancefloors" (Sporadical 1997: 3$).{ }^{28}$

The Jellyheads/Vibe Tribe, punk/techno combination reflected a new wave of self-valorisation for anarcho-punk. Under a DIY ethos, punks would become occupied outside or adjacent to the labour market - making music, producing zines and running workshops. At the same time, they were participating in an emergent outdoor party culture. "In a spirit of adventure", during the mid 1990s "all these people got 
themselves out of their apathetic moment and had gone out to these beautiful bush settings, to the country or to the desert or to the beach".29 And the reclaimed sites, squatted buildings and bush-doof trajectory would enable initiatives with a proactive counter-colonial character. As direct anti-corporate activism was gathering strength globally through the 1990s, post-punk elements were acting locally.

\section{Techno Circus and Desert Punks}

Vibe Tribe's ambition was to mobilise a non-profit, non-waged traveling circus incorporating performance art, installations and music. So motivated, they were inspired by UK sound systems and European "circus tribes" who had "embraced the rise of electronic music fusing liberationist politics with technology" (Strong, Sporadical \# 1 1994). Spiral Tribe and other techno tribes like Bedlam and Desert Storm were the product of a techno-traveller-punk moot in the late eighties which would see punk take to the road in a post-apocalyptic - Mad Max meets Judge Dread inflected - revision of the New Age Traveler lifestyle and festival. In Europe, techno-punk "teknivals" gained popularity by the mid-1990s. In the wake of the salvage-Situationist adventures of London's Mutoid Waste Co (see Cooke 2001), and the UK acid house explosion, the disenchanted and disenfranchised were seceding from the parent culture. Yearning for more than the temporary escapade of the TAZ, they would satiate their desire for difference by escaping the confines of Britain (where, by 1994, the notorious Criminal Justice Bill had been enacted). Forming in 1991 under the slogan "make some fucking noise", London's Spiral Tribe were the trailblazers of an international techno-circus, whose sites contextualised techno-culture's performance to itself - reaffirming a techno-punk identity. Describing their relentless performance, one observer saw the Spirals "promising something and then screaming ultrasonic violent chaos... Rhythms careering forward piling into the future, bellowing into the sky, and then a voice sampled YOU DON'T KNOW WHAT YOU'RE DEALING WITH” (Stroud 1994)..$^{30}$

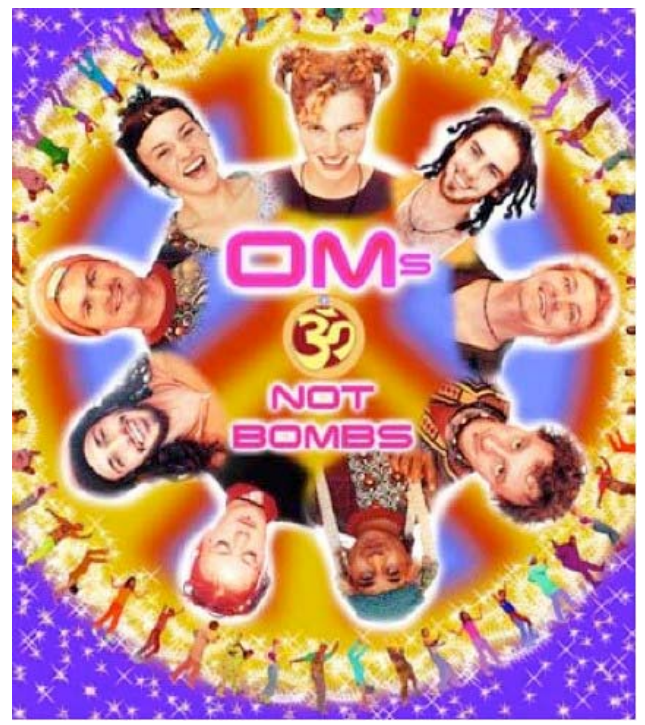

Figure 7: Oms not Bombs (later called Ohms not Bombs) 
While Vibe Tribe were similarly drawn to the road - a compulsion assisted by South Sydney Council's hostility to their inner city presence - the Australian technomadic adventure would await the arrival of Ohms not Bombs. A direct result of the techno-punk experiments discussed above, Ohms was also an extraordinary fusion of anarcho-punk and the "rave-olutionary" technophile counterculture of early 1990s San Francisco. ${ }^{31}$ Initially consisting of around 20 musicians, artists and activists, Ohms was formed (in 1995) to catalyse a movement for a nuclear free future and sovereignty for Indigenous Australians.
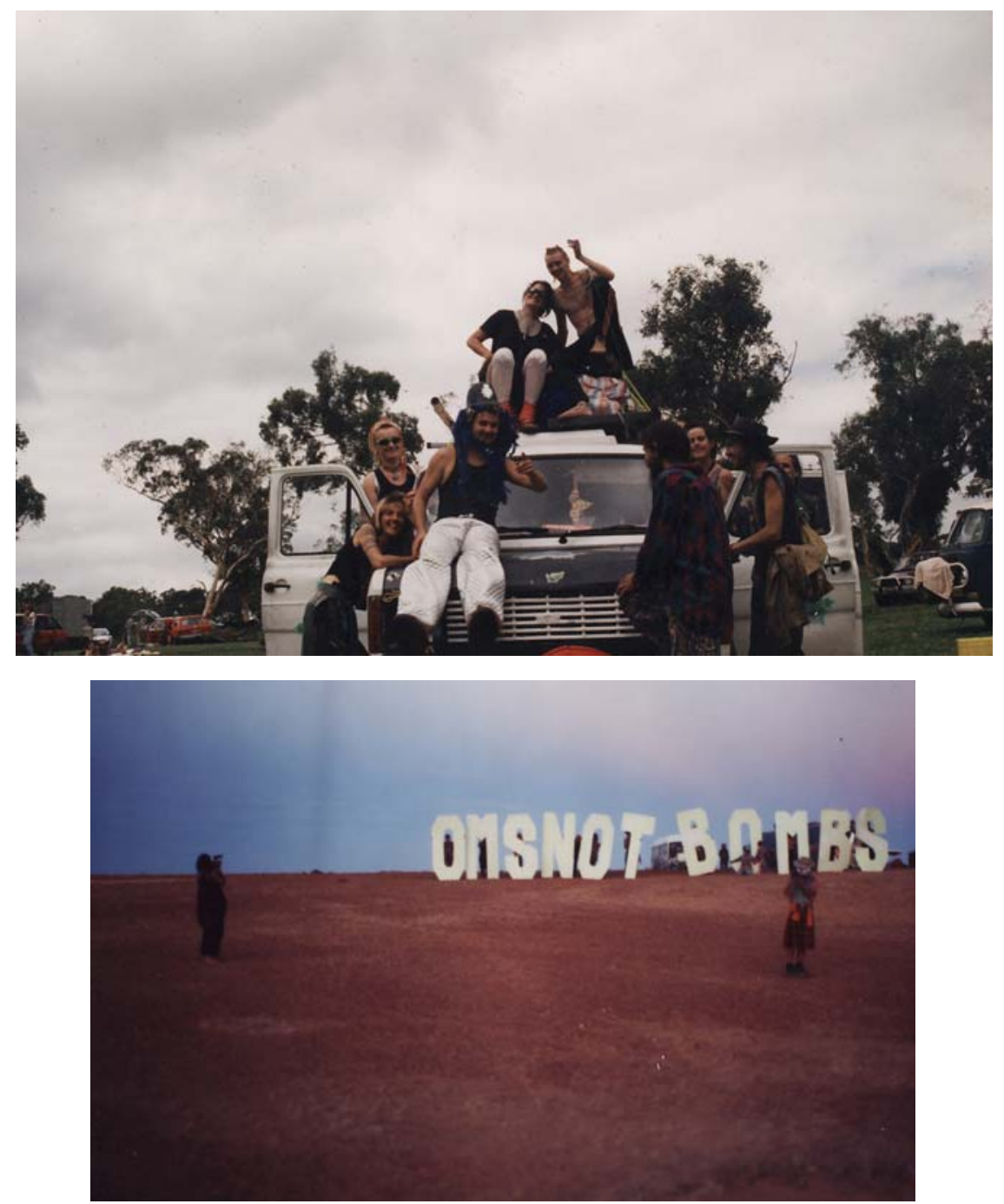

Figure 8, 9: Oms not Bombs (later called Ohms not Bombs) - Photo by Peter Strong

The collective emerged amid outrage at French nuclear weapons testing in the Pacific. They were originally "Oms not Bombs", the name inspired by Food Not Bombs where the "Om" ( $\left.{ }^{\circ}\right)$ substitute "represents universal peace in the ancient Sanskrit symbology". They would later become known as "Ohms not Bombs".32 The 
brainchild of expatriate Londoner Strong, Ohms renovated an old State Transit bus and drove it around Australia on their 1998 Dig the Sounds Not Uranium tour.

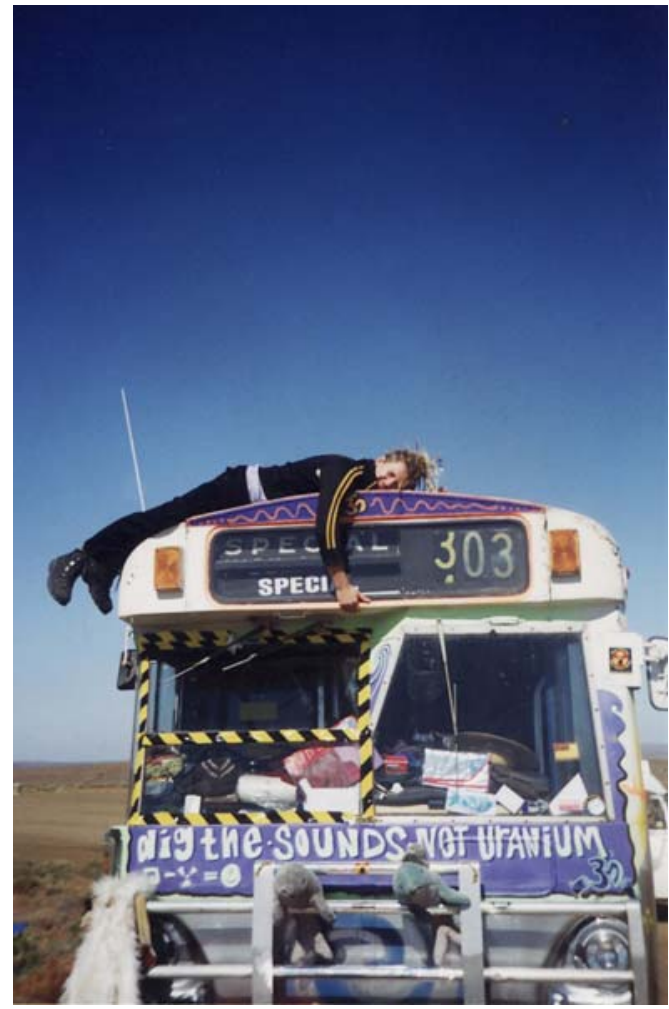

Figure 10: Dig the Sounds Not Uranium. Photo by Pete Strong

The tour involved 30 events (doofs, actions, music workshops) held over four months before Ohms reached Jabiluka uranium mine in the Northern Territory's Kakadu National Park. ${ }^{33}$ Dig the Sounds was a traveling multi-media sound system, a "Mobile Autonomous Zone", motivated by a desire to "promote grassroots reconciliation respecting the original people of the land" and to "catalyse further actions and ideas about breaking the nuclear cycle locally and globally" (Sporadical 5 1998: 8). While commentators recalled the American transcontinental ramblings of the protohippy electro-tribal Merry Pranksters three decades prior (Daly 1999: 9), with a syncopated audio-visual apparatus and information stalls communicating anti-nuclear and other ecological and indigenous justice issues, this was no "acid test" but a mobile tactical media assemblage Strong labeled a "doofumentary". Undertaking an independent initiative within a "reconciliatory" climate, ${ }^{34}$ Ohms was driven by Strong's vision of tapping the party "vibe" for extra-party purposes: "unity is strength, together we can dismantle oppression, lets have the NRG we have developed on the dancefloor and use it to mutate the state, derail the earth destroying system. By tuning our funky technology to the cycles of our Earth's ecology we can crossfade towards a brighter future for all" (Strong and Strong 2000). And with an improtopian mission to the outback, the Ohms movie became "a noughties version of Ken Kesey's Merry Pranksters meets a Russian Revolution propaganda train meets Priscilla, Queen of the Desert!" (Murray 2001: 67). ${ }^{35}$ 


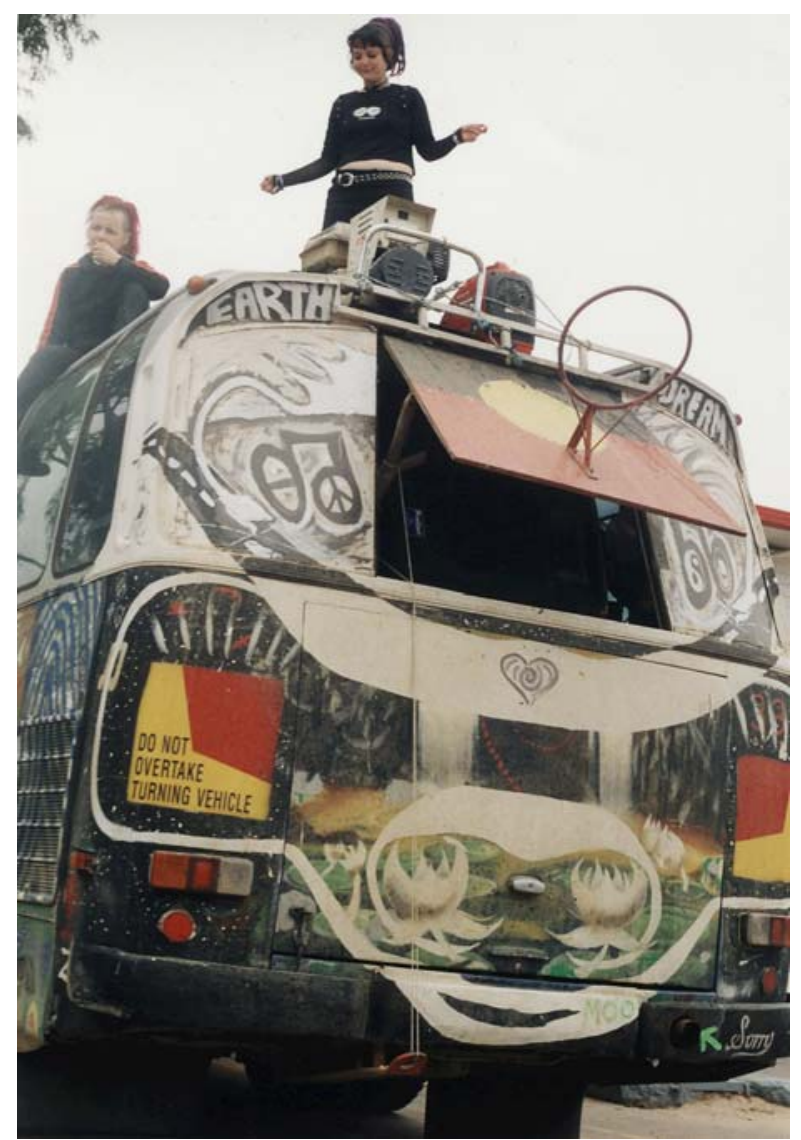

Figure 11: Ohms not Bombs - Peace Bus. Photo by Peter Strong

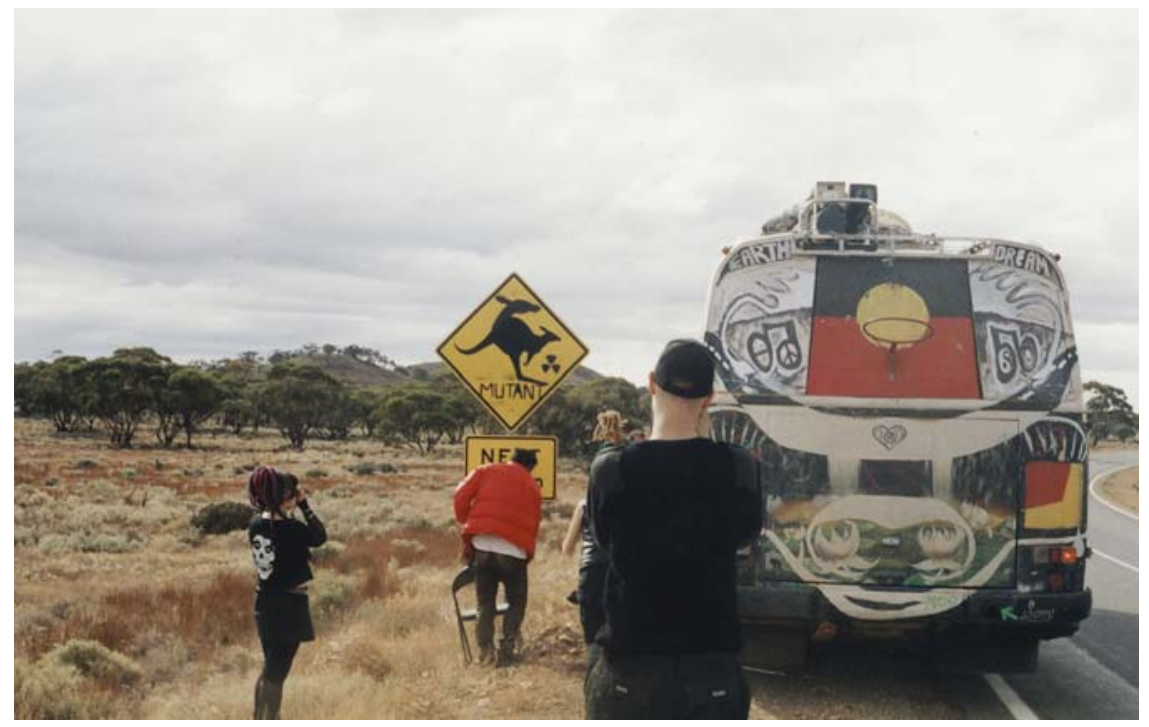

Figure 12: Ohms not Bombs - Peace Bus. Photo by Peter Strong 
The "doofumentary" provided an inspiration for the Labrats alternative energy sound system. With a solar powered PA and a wind-powered cinema hauled by a van with an engine converted to run on vegetable oil, Labrats were an innovative sound system presence. Street performer, cartoonist and "human techno beat-box", Izzy Brown, and trained geologist, funk, reggae and dub selector-producer Marc Peckham, met in 1998 at Jabiluka where they were exposed to the Ohms road show and combined to entertain and enthuse fellow campaigners. With Brown and Peckham subsequently responding to Arabunna elder Kevin Buzzacott's call for assistance, the Labrats would mobilise to support his opposition to Western Mining Corporation (WMC) in outback South Australia - joining the Keepers of Lake Eyre, $180 \mathrm{~km}$ north of Roxby Downs. ${ }^{36}$ Adopting a direct dance-activism and jacking into sustainable power sources, they would constitute the soundest system yet seen. As they asserted, the solar powered sound system pulled "the party scene back to its roots as a revolutionary force of beats and breaks, bleeps and squeaks in the face of an authority that is destroying our environment and the people that depend on it for their survival" (Brown and Peckham 2001: 92). Developing a multimedia assemblage inflected with techno, message rap, funk and reggae traditions, and participating in Reclaim the Streets and alternative media festivals, the Labrats communicated their antagonism with mining companies and promoted their living alternative to audiences in outback locations and metropolitan centres Australia-wide. ${ }^{37}$

http://www.youtube.com/watch?v=u7QvWzLX7-Y

Tunin' Technology to Ecology part 1

http://www.youtube.com/watch?v=w86qOuUlBwc

Tunin' Technology to Ecology part 2

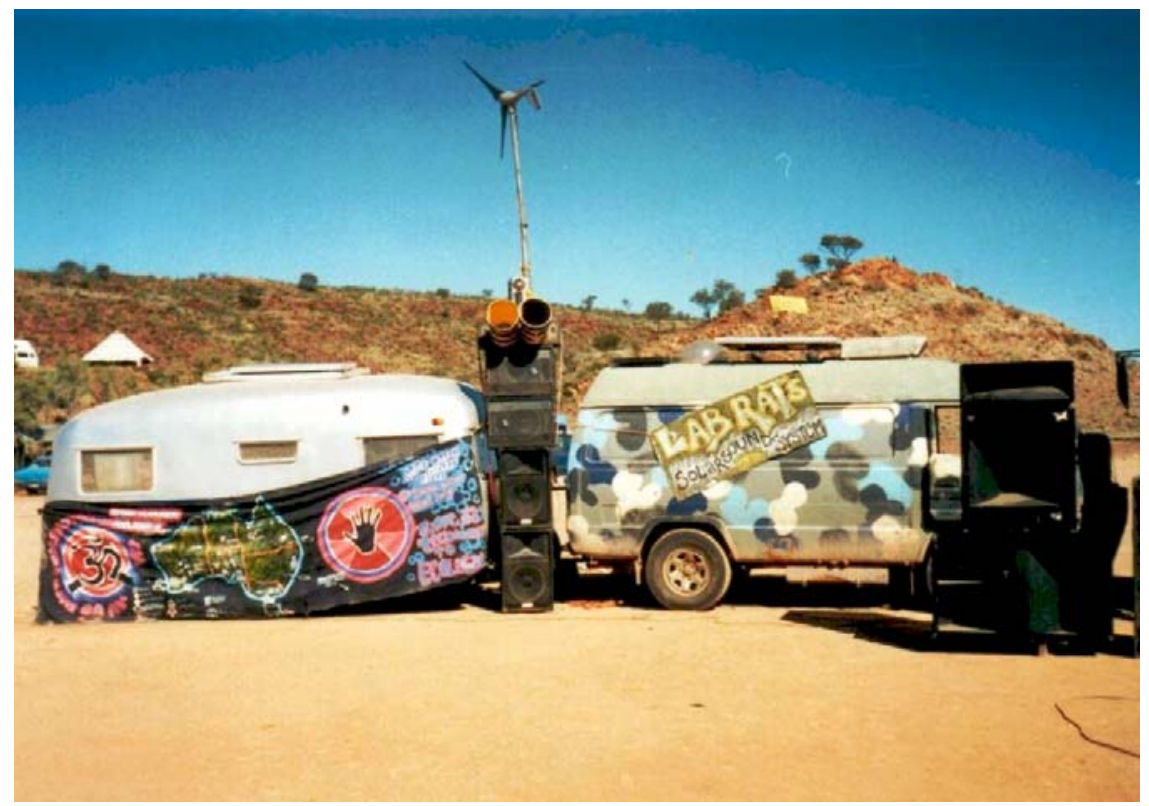

Figure 13: Labrats Sound System at The Claypan, Alice Springs, June 2000. Photo by Graham St John 
The message was principally amplified via their band Combat Wombat, which Marc informed me is "punk hop" in orientation - the term denoting inheritance from both anarcho-punk and the message rap of the likes of Public Enemy. Including DJ Monkey Marc, MC Izzy, MC Elf Transporter, and DJ Wasabi (and occasionally Miranda Mutanta, MC Anna, and DJ Atom13, Combat Wombat gained national underground notoriety with their second album Unsound \$ystem (2005), especially with the track "Qwest".

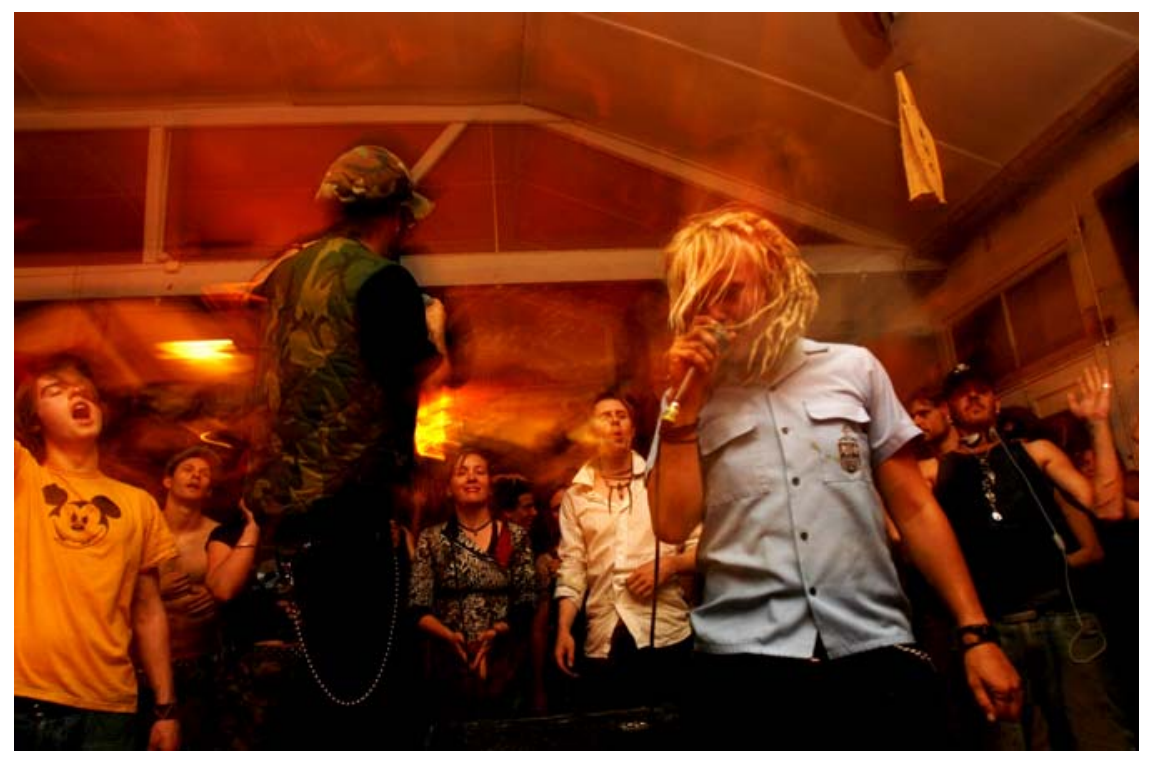

Figure 14: Combat Wombat. Photo by Andrew Kelly: andrewkelly.com.au

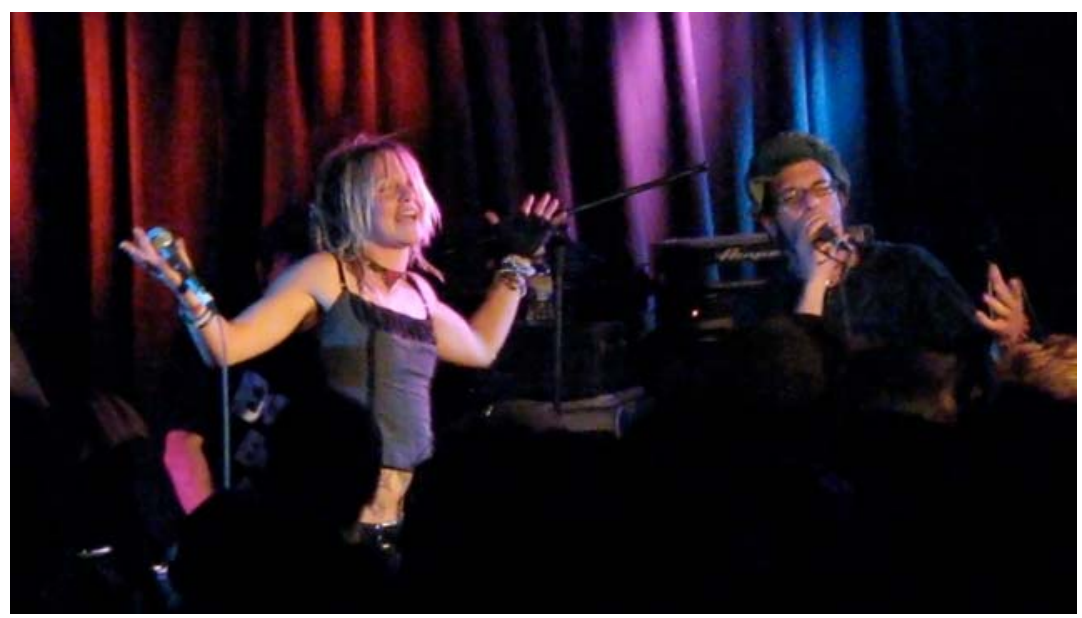

Figure 15: MC Izzy and Elf Transporter at the Northcote Social Club. Photo by Peter Halasz: flickr.com/photos/pengo-au

http://www.youtube.com/watch?v=Nttjxl8MIZg

Combat Wombat: Qwest 
One of the most compelling features of Labrats/Combat Wombat was the remarkable level of playback immediacy in their performances. The issues of moment - especially the impact of the uranium industry on Aboriginal communities - have been articulated via vocal samples and live MCing born from direct experience in desert regions of South and Central Australia from 1999.38 As Marc stated, "it's first hand information... It just comes straight from our mouths which has just come directly from what we've seen. We record it and that's it. It's an adulterated, uncensored version". ${ }^{39}$ Their music is thus consistent with a punk (and blues, folk, hip hop) tradition conscious of transmitting a rawer and "truer" version of events (issues) through proximity to the streets (social marginality). And while the language of the "streets" to which Labrats were versed derives from middle class self-marginality, they nevertheless make claim to a genuine intimacy with the margins enabling a highly respected interpretation of events. Unlike early sound system models, Labrats "noise" was determined as much by a compulsion to "make a difference" as to be different (noisy). In choosing a marginal life, Combat Wombat/Labrats subordinated themselves to possibility - to a possible future. Committed to "make things right", their effort has been one of living the future in the present. Responding to the "call" of custodians, the "future-presence" consists of intimate reconciliation, support for Aboriginal sovereignty and a connection with threatened country. And using an assemblage of sonic, visual and alternative media, these terra-ists embarked upon a mission to unite a scene in a "fight for country".

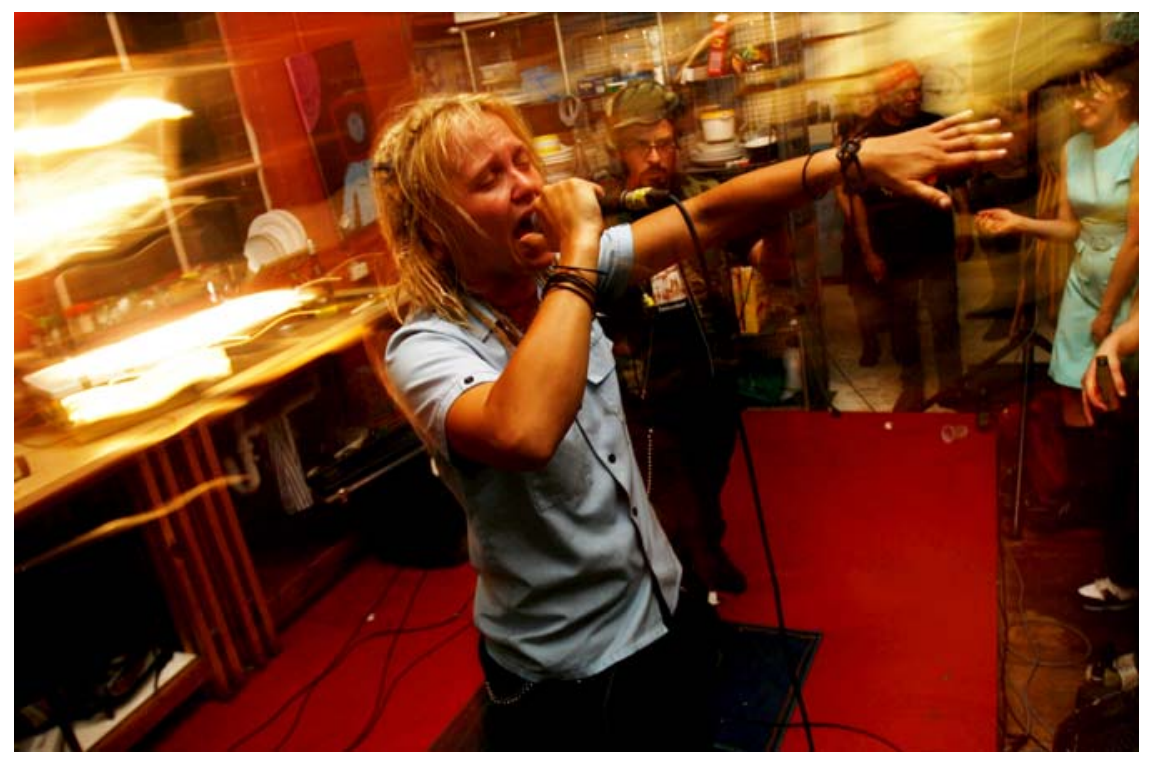

Figure 16: MC Izzy. Photo by Andrew Kelly: andrewkelly.com.au 


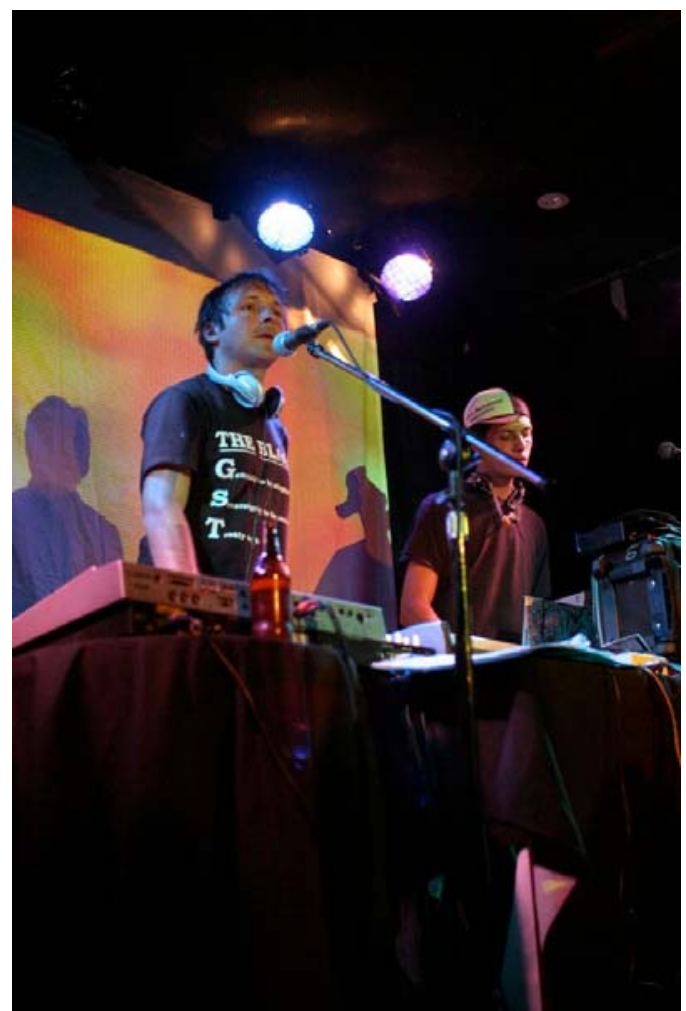

Figure 17: Monkey Mark and DJ Wasabi. Photo by Damon Rao:Alickr.com/photos/urbanbicyclist

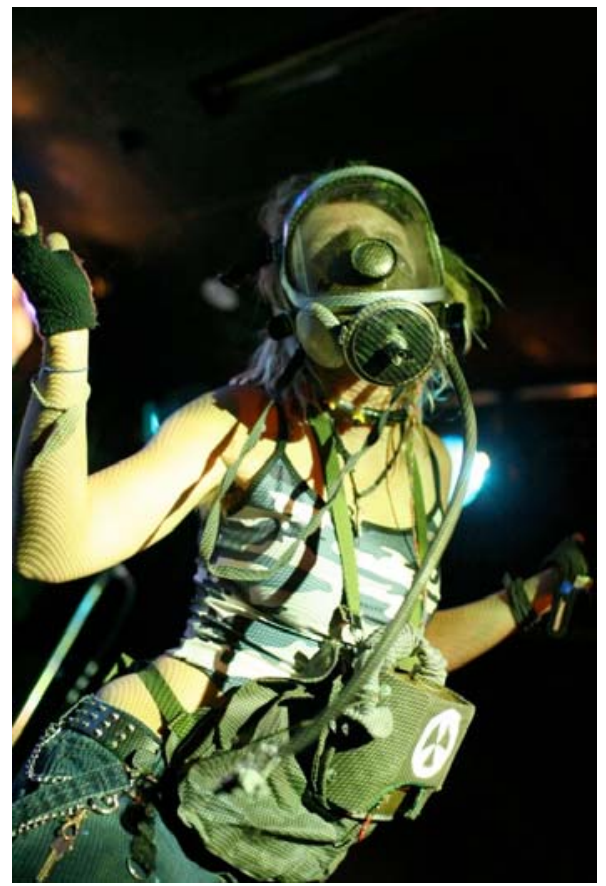

Figure 18: MC Izzy at Northcote Social Club. Photo by Damon Rao: flickr.com/photos/ urbanbicyclist 


\section{Conclusion}

In an effort to comprehend trajectories downstream from punk, exploring the boundaries crossed between punk, techno and hip hop, this article has travelled to the conceptual heart of "hardcore". The discussion of what it means to be authentically hardcore, a theme appropriated by punks to define their own scene, albeit a process not unique to punk, assists our understanding of how and why scenes cross over, and why new scenes emerge in the first place.

The discussion of musicians and activists mobilising within a settler society struggling for legitimacy has provided the context for these observations. Labrats/ Combat Wombat and other agitators influenced by DIY experimental music and activist traditions have emerged in a period influenced by the anti-corporate challenge from anarcho-punk. The 1990s saw the explosion of simultaneous aesthetic and activist dispositions characteristic of that which I have identified as "hardcore". Adopting new music technologies, methods and aesthetics, post-punk actors intervened to express difference and/or make a difference in varied responses to conditions of inequality, injustice and despoliation. A punk trajectory would be sustained through proximity to the "streets" and commitment to a "cause" (outside of conventional artistic and political frameworks) - a cause which in Australia developed a strong counter-colonial character. Ohms not Bombs and Labrats were likened to "stormtroopers spearheading a generation's demands" that their continent's ecosystems be safeguarded from the radioactive perils of the nuclear industry (Daly 1999: 9). But as the interventions of these techno-protagonists conveyed, more than a nuclear-free future was at stake. They would be implicated in a movement for legitimate presence, which relied on the adoption of intimate and tactical audio technologies. In Sydney in the early 1990s, a collective sound system model was adopted in the wake of a dynamic punk-techno convergence associated with the Jellyheads alternative music project. At that time, new audio digital technologies enabled adherence to a politics of difference involving independent and decentralized musical creativity. Using these new technologies and techniques, anarcho-techno musicians (exemplified by Non Bossy Posse) amplified anti-corporate and non-authoritarian liberationist messages at autonomous "improtopias" facilitated by the Vibe Tribe, a collective providing stimulus for mobile initiatives responding to the threat to "country". Not an inflection of the Mad Max "road warrior" who knows no future, and who respects no authority other than the road itself, post-punk techno terra-ists would mount creative solutions in a post-settler becoming. While there can be little doubt that this local momentum shifted as a result of competing commitments associated with the late-1990s alter-globalisation movement and the antiwar movement of the 2000s, sustained comparison with more contemporary technoactivist developments in Australia and elsewhere should prove rewarding.

\section{References}

Balliger, Robin. 1995. "The Sound of Resistance”. In Ron Sakolsky and Fred Wei-Han Ho (eds.), Sounding Off: Music as Subversion/Resistance/Revolution, pp. 13-26. New York: Autonomedia.

Beezer, Anne. 1992. "Dick Hebdige, Subculture: The Meaning of Style”. In Martin Barker and Anne Beezer (eds.), Reading into Cultural Studies, pp. 101-18. London: Routledge. 
Bey, Hakim. 1991a. TAZ: The Temporary Autonomous Zone - Ontological Anarchy and Poetic Terrorism. New York: Autonomedia.

----. 1991b. “The Lemonade Ocean and Modern Times: A Position Paper”. <www.spunk.org/ texts/writers/bey/sp000917.txt> (accessed 8 October 2009).

----. 1994. Immediatism. Edinburgh: AK Press.

Brown, Izzy and Mark Peckham. 2001. “Tuning Technology to Ecology: Labrats Sola Powered Sound System”. In Graham St John (ed.), FreeNRG: Notes from the Edge of the Dance Floor, pp. 91-107. Melbourne: Common Ground. <undergrowth.org/ freenrg notes from the edge of the dancefloor $>$ (accessed 8 October 2009).

Chan, Seb. 1997. 'The Cops are Jammin' the Frequency': Critical Moments for the Sydney Free Party Scene. Unpublished manuscript. <www.cia.com.au/peril/youth/index.htm> (accessed 13 June 2007).

----. 1999. "Bubbling Acid: Sydney's Techno Underground”. In Rob White (ed.), Australian Youth Subcultures: On the Margins and in the Mainstream, pp. 65-73. Hobart: ACYS Publications.

Clark, Dylan. 2003. "The Death and Life of Punk: The Last Subculture”. In David Muggleton and Rupert Weinzierl (eds.), The Post-Subcultures Reader, pp. 223-36. Oxford: Berg.

Cohen, Michael, Paul Dwyer, and Laura Ginters. 2008. "Performing 'Sorry Business': Reconciliation and Redressive Action”. In Graham St John (ed) Victor Turner and Contemporary Cultural Performance, pp. 76-93. New York: Berghahn.

Cooke, Robin. 2001. "Mutoid Waste Recycledelia and Earthdream”. In Graham St John (ed.), FreeNRG: Notes from the Edge of the Dance Floor, pp. 131-156. Altona: Common Ground. <undergrowth.org/freenrg_notes_from_the_edge_of_the_dancefloor> (accessed 8 October 2009).

Cutler, Chris. 1995. "Plunderphonics”. In Ron Sakolsky and Fred Wei-han Ho (eds.), Sounding Off: Music as Subversion/Resistance/Revolution, pp. 13-26. New York: Autonomedia.

Daly, Mick. 1999. “Doof Warriors: Turning Protests into Parties”. Sydney City Hub, 9. June 17.

Deleuze, Giles, and Felix Guattari. 1986. Nomadology : The War Machine. New York: Semiotext(e).

Edge, Brian. (ed). 2004. 924 Gilman: The Story So Far. San Francisco: Maximumrocknroll.

Ferrell, Jeff. 2001. Tearing Down the Streets: Adventures in Urban Anarchy. New York: Palgrave.

Fitzgerald, John. 1998. "An Assemblage of Desire, Drugs and Techno”. Angelaki: Journal of the Theoretical Humanities 3(2): 41-57

Gilbert, Jeremy, and Ewan Pearson. 1999. Discographies: Dance Music, Culture and the Politics of Sound. London: Routledge.

Gooder, H and J Jacobs. 2000. "'On the Border of the Unsayable': The Apology in Postcolonizing Australia”, Interventions 2(2): 229-247.

Hemment, Drew. 1996. "E is for ekstasis". New Formations 31: 23-38.

Hesmondhalgh, David. 1998. “The British Dance Music Industry: a Case Study of Independent Cultural Production”. British Journal of Sociology 49(2): 234-51.

Huq, Rupa. 2002. "Raving, not Drowning: Authenticity, Pleasure and Politics in the Electronic Dance Music Scene". In David Hesmondhalgh and Keith Negus (eds.), Popular Music Studies, pp. 90-102. London: Arnold.

Jacobs, John and Pete Strong. 1995/96. Is this R@ve olution? <sysx.org/vsv/ideas.html> (accessed 21 March 2007).

Jordan, John. 1998. "The Art of Necessity: The Subversive Imagination of Anti-Road Protest and Reclaim the Streets". In George McKay (ed.), DIY Culture: Party and Protest in Nineties Britain, pp. 129-51. London: Verso.

Jordan, Tim. 2002. Activism! Direct Action, Hacktivism and the Future of Society. London: Reaktion Books.

Keir, Milburn. Punk and Autonomia. <www.uncarved.org/music/apunk/autonomia.html> (accessed 8 October 2009). 
Lawrence, Tim. 2003. Love Saves the Day: A History of American Dance Music Culture, 1970-1979. Durham and London: Duke University Press.

Lentini, Pete. 2002. "Melbourne Punk: A 'Banal' Politics of Difference”. Paper presented at the 8th IASPM, University of Technology, Sydney.

Luckman, Susan. 2003. "Going Bush and Finding One's 'Tribe': Raving, Escape and the Bush Doof". Continuum: Journal of Media and Cultural Studies 17(3): 315-30.

Maffesoli, Michelle. 1993 [1982]. The Shadow of Dionysus: A Contribution to the Sociology of the Orgy. Albany: State University of New York Press.

----. 1996 [1988]. The Time of the Tribes: the Decline of Individualism in Mass Society. London; Thousand Oaks, California: Sage.

McKay, George (ed.). 1998. DIY Culture: Party and Protest in Nineties Britain. London: Verso.

Murray, Enda. 2001. "Sound Systems and Australian DiY Culture: Folk Music for the Dot Com Generation”. In Graham St John (ed.), FreeNRG: Notes From the Edge of the Dance Floor, pp. 57-70. Altona: Common Ground. Lundergrowth.org/ freenrg notes from the edge of the dancefloor > (accessed 8 October 2009).

O’Neill, Shannon. 2009. "'Copyright Doesn't Mean Shit to Me': Sampling and Appropriation in Australian Experimental Music and Sound Art." In Gale Priest (ed), Experimental Music: Audio Explorations in Australia, pp. 75-93. Sydney: UNSW Press.

Reynolds, Simon. 1998. Energy Flash: A Journey Through Rave Music and Dance Culture. London: Picador.

Schechner, Richard. 1992. "Invasions Friendly and Unfriendly: the Dramaturgy of Direct Theatre". In Janelle Reinelt and Joseph Roach (eds.), Critical Theory and Performance. Ann Arbor: University of Michigan.

Shantz, Jeff. 1999. "The New World in the Shell of the Old". Arachne 6(2): 59-75.

Shapiro, Peter. 2005. Turn the Beat Around: The Secret History of Disco. New York: Faber and Faber.

Sicko, Dan. 1999. Techno Rebels: The Renegades of Electronic Funk: Billboard Books.

St John, Graham. 1999. "Ferality: A Life of Grime". The UTS Review - Cultural Studies and New Writing 5(2): 101-13.

----. 2000. "Ferals: Terra-ism and Radical Ecology in Australia". Journal of Australian Studies, 64: 208-16.

----. 2001a. "Australian (Alter)Natives: Cultural Drama and Indigeneity". Social Analysis, 45(1): 122-40.

----. 2001b. "Doof! Australian Post Rave Culture". In Graham St John (ed.), FreeNRG: Notes From the Edge of the Dance Floor, pp. 9-36. Altona: Common Ground. < undergrowth.org/freenrg notes from the edge of the dancefloor> (accessed 8 October 2009).

----. 2001c. "Techno Terra-ism: Feral Systems and Sound Futures". In Graham St John (ed.), FreeNRG: Notes From the Edge of the Dance Floor, pp. 109-27. Melbourne: Common Ground. <undergrowth.org/freenrg notes from the edge of the dancefloor> (accessed 8 October 2009).

----. 2004. "Counter Tribes, Global Protests and Carnivals of Reclamation". Peace Review: A Journal of Social Justice 16(4): 421-28.

----. 2005. "Outback Vibes: Sound Systems on the Road to Legitimacy”. Postcolonial Studies: Culture, Politics, Economy 8(3): 321-36.

----. 2006. "Reclaiming the Future: Going Feral and Becoming Native at Goolengook". In Lynne Hume and Kathleen McPhillips (eds) Popular Spiritualities: The Politics of Contemporary Enchantment, pp. 187-196. Aldershot: Ashgate.

----. 2008. "Protestival: Global Days of Action and Carnivalized Politics in the Present". Social Movement Studies: Journal of Social, Cultural and Political Protest. 7(2): 167-90.

----. 2009. Technomad: Global Raving Countercultures. London: Equinox.

Stephens, Julie. 1998. Anti-Disciplinary Protest: Sixties Radicalism and Postmodernism. Cambridge; New York: Cambridge University Press. 
Strong, Peter. 2001. "Doofstory: Sydney Park to the Desert". In Graham St John (ed.), FreeNRG: Notes From the Edge of the Dance Floor, pp. 9-36. Altona: Common Ground. < undergrowth.org/freenrg_notes_from_the_edge_of_the_dancefloor $>$ (accessed 8 October 2009).

Strong, Peter and Faith Strong. 2000. "Oms Not Bombs". In Alan Dearling and Brendan Handley (eds), Alternative Australia: Celebrating Cultural Diversity, pp. 144. Dorset: Enabler.

Thornton, Sarah. 1995. Club Cultures: Music, Media and Subcultural Capital. Cambridge: Polity Press.

\section{Filmography}

Labrats. Tunin' Technology to Ecology. 2003. Youtube:

Part One <www.youtube.com/watch?v=u7QvWzLX7-Y>

Part Two <www.youtube.com/watch?v=w86qOuUlBwc>

\section{Discography}

Combat Wombat. 2002. Labrats Solar Powered Sound System (CD).

Combat Wombat. 2005. Unsound \$ystem. Elefant Traks (CD).

Monkey Marc. 2003. Western Desert Mob. Warumpi Studio (CD).

----. 2009. As the Market Crashed. Omelette Records (CD).

Non Bossy Posse. 1993. Saboteurs of the Big Daddy Mind Fuck (Cassette tape).

Organarchy. 1998. Filthy Jabilucre (CD).

Organarchy. 2001. Activista (LP).

\section{Author Biography}

Graham St John is a Research Associate at the Centre for Critical and Cultural Studies at the University of Queensland. His latest books include Technomad: Global Raving Countercultures (Equinox, 2009) and the edited collection The Local Scenes and Global Culture of Psytrance (Routledge, 2010). He is the Executive Editor of Dancecult. See: www.edgecentral.net

\section{Notes}

1 From a line in the song "White Australia" on Labrats (Combat Wombat's) debut album Labrats Solar Powered Sound System (2002).

2 On "Punk Is" from Labrats Solar Powered Sound System (2002).

3 The article focuses almost exclusively on developments in Sydney (and I make no claim to providing a comprehensive coverage of scenes in that city). The contribution of scenes elsewhere in Australia could not be adequately addressed in this article. This is not an exploration of Australian hardcore punk.

4 Or that which George McKay (1998) recognises, perhaps more accurately, as a "Do It Ourselves" approach, which was inherited from the Industrial Workers of the World (IWW or Wobblies) and other anarchist precedents through countercultural forebears. It is of course curious that, often misrepresented and dismissed as apathetic, gullible and naïve in popular media throughout the 1970s and 1980s (see Stephens 1998: 79), the sixties counterculture (hippies) were generally despised by earlier punks.

5 See Reynolds in this edition of Dancecult, and articles by Jeremy Gilbert and Mark Fisher in Dancecult: Journal of Electronic Dance Music Culture volume 1 issue 1. 
From a presentation delivered at FACT, Liverpool (11th February 2009). Text at: <energyflashbysimonreynolds.blogspot.com/2009/02/hardcore-continuum-or-theory-a nd-its.html> (accessed 10 October 2009).

Not only inheriting the "anti-disciplinary protest" of countercultural formations (like the Diggers and the Up Against the Wall Motherfuckers), anarcho-punk would derive stimulus from Dutch squatters and German Autonomes, themselves inheriting something of the Italian Autonomia movement. The latter is regarded as a pragmatic anti-capitalist movement where "the ultimate resort is not to the claim of authenticity but to one of efficacy" (Keir).

Commitments resonating with Deleuze and Guattari's (1986: 4) nomad who might "deterritorialize oneself by renouncing, by going elsewhere" or "deterritorialize the enemy by shattering his territory from within".

In the early 1990s Bey was referring to small press, community radio, and the possibilities of the Internet. E-forums and email lists along with audio and video technology could certainly be added to this list. "Intimate media" is discussed in Bey's "Media Hex: The Occult Assault On Institutions" <www.t0.or.at/hakimbey/hex.htm> and in "Media Creed For The Fin De Siecle" <www.left-bank.org/bey/mediacr1.htm> (both accessed 8 October 2009). By the mid 1990s, Bey's net-disseminated work, particularly his poetic tract The TAZ (1991a), was becoming widely read and debated within anarcho-punk, rave and other alternative circles globally.

The conceptual architecture of the TAZ was imagined to expose "the enemy" ("separation" and "sameness" via mediation and commodification) and incite "the cause" ("the new autonomy" of "presence" and "difference") (Bey 1994). While elements of post-punk are sympathetic to the idea of a "free association of individuals" who "depend neither on Capital nor any other form of representation", others veer widely from Bey's sophisticated and non-ideological "individualist anarchism" (Bey 1991b).

For Reclaim the Streets see Jordan (1998). The June 181999 Global Street Party coincided with the G8 Summit in Cologne. For a discussion of the "protestival" see St John (2008).

For good coverage of the rock industry's (and Middle America's) reaction to disco, see Peter Shapiro (2005) and Tim Lawrence (2003: 376)

See St John $(2004,2009)$ for a discussion of the role of rave and Reclaim the Streets in the gathering carnival of protest.

Adopted by Guy Debord and the Situationists, détournement was an early term for "culture jamming", a set of progressive aesthetic tactics performed initially in the urban streetscape designed to expose the desires and relationships which the capitalist "Spectacle", particularly through the machinations of the advertising industry, routinely renders "natural".

5 The last two samples are from "Plan it" on the Activista LP (2001).

Jeh Kealin, email correspondence, 16 June 2004.

Grant “Zippy” Focus, email correspondence, 13 June 2004.

Radio Skid Row provided the context and resources for many in the punk and independent scenes to develop their talents. For instance, Seb Chan (Yellow Peril) and Luke Darnley (Lex Luther), who formed their live hardcore industrial project Sub Bass Snarl in 1991 and later ran the Cryogenesis chillout project and the Frigid club nights, ran various dance and experimental shows in the early 1990s including one following the activist punk program Oxford Babylon (Seb Chan, email correspondence, 6 July 2004). 
The anarchist cultural centre ran a variety of fundraising events including Jellyvision video nights by Subvertigo, Jellywomen feasts, the Eat the Rich Cafe and performances by the Unknown Theatre Company. It was also a breeding ground for Cat@lyst (Community Action Technology), a collective who would make the Internet available to community activists, and who were responsible for creating the open-source self-publishing software used by Indymedia.

Mahatma Propagandhi formed in 1989-1990 and originally consisted of John Jacobs, Tony Collins and Craig Domarski (all of whom worked on a Triple J program called "The Works" which was a "a live freewheeling mix", an experimental lab for later developments). The band had a previous incarnation as the KGB Stooges, who performed a cover of Crass' "Do they owe us a living?", and, as the Media Liberation Front, played an antimedia oligarchy performance at the Sydney Stock Exchange in 1988. Pete Strong, who had performed gigs with his Sound Anti-System, and who did screen printing for the University of New South Wales, met Jacobs at a Gulf War rally on Palm Sunday at Circular Quay in 1991, joining Mahatma Propagandhi soon afterwards. John Jacobs, email correspondence, 9 June 2004. John Jacobs, email correspondence, 9 June 2004.

Mike J gained particular notoriety when failing to pay those he hired for a Meat Beat Manifesto party in Redfern in 1994. This climate triggered the popular graffiti "Virtual Basstards".

John Jacobs, interview with the author, ABC studios, Sydney, 31 March 2004.

NBP productions would subvert the status of art as an "original" or "individual" work, and by implication threaten the idea of property rights. This was the case for audio as much for text and image (especially with regard to event posters, the zine Sporadical and photomontaging). For a discussion of appropriation and anti-copyright practices in Australian experimental music see Shannon O’Niell (2009).

NBP played their first gigs at the Wobble parties - named after the Wobblies.

Sites where, much like Bey's TAZ, the artist is not a special sort of person, but every person is a special sort of artist (1991: 70).

28 By 1995, Vibe Tribe's unlicensed party culture would generate a malicious response from the South Sydney Council. On the April 11 that year, several hundred people at a Sydney Park event (Freequency) were violently dispersed by police (see Chan 1997; Strong 2001: 77-8).

29 Vibe Triber and founder of the Sydney breakcore collective, System Corrupt, Kirilli (aka DJ Zeitgeist) indicates how hardcore artists have been surfing the edge of techno music and activism. Breakcore indicates the effort to "distort the hell out of... classic tribal breaks", to "cut them up and just infuse them in radical yet somehow rhythmical ways". At System Corrupt events "what we're attempting to do", she says, "is invite people to just hack at their rigid thought forms and open up their minds to new ideas there and then". In stating that "we are inherently connected to the land and politics and... we're connected with [indigenous] people because the land issues are just so important", Kirilli reveals what these "new ideas" might entail. "Our party system", she stated, "has got a point" (interview conducted with the author, Newtown, Sydney, 1" May 2004).

30 Making the exodus from the UK, these sound systems would travel widely (e.g. Europe, the US and Australia) inspiring organisations such as San Francisco's SPAZ (Semi Permanent Autonomous Zone).

31 For example, the first edition of Strong's Sporadical ran an article on "Cyber-Tribe Rising" which referred to technologically enhanced cooperatives evincing "a new breed of individuals [who] have a unique chance to make a difference in the world we live in". 
According to Strong, "ohms" is "a symbol of resistance [which]... can apply to sound or the mass of people power needed in our non-violent war against the enemies of the earth" (Strong 2001: 82, 87).

In 1997 Energy Resources of Australia Ltd (ERA) received Howard Government approval to build a uranium mine at Jabiluka in the World Heritage listed Kakadu. In 1998, representatives of the Mirrar traditional owners called on supporters to join their struggle to protect the area's cultural and environmental values. After a lengthy blockade, further construction of the mine ceased in 1999, and Rio Tinto (majority shareholders of ERA) began rehabilitating the mine site in October 2003.

It was known as the "Decade of Reconciliation" after the setting up of the Council for Aboriginal Reconciliation in 1992.

For more detail on the origins of this tour and its outcomes such as Organarchy's Filthy Jabilucre CD (1998), see St John (2001c).

Representing a threat to the physical and cultural survival of Arabunna, WMC had been mining and milling one of the world's largest uranium ore deposits at Olympic Dam, Roxby Downs since 1988. WMC's growing demands on underground water sources in one of planet's driest regions had a devastating impact on Arabunna and Kokatha peoples since such sources feed the precious springs around the Lake Eyre region essential for their cultural survival. BHP Billiton acquired WMC Resources in 2005.

37 Labrats towed a caravan housing a solar/wind/vegetable oil powered recording studio and computer with video editing software. In 2003, their film documentary Tunin' Technology to Ecology won a New Filmmakers Award at the Wild Spaces environmental and social justice film festival.

Marc travelled outback and top-end locations throughout the decade working with indigenous children creating socially conscious hip hop, conducting cultural preservation workshops and oral history recordings (see St John 2009: chapter 7). This work resulted in the album Western Desert Mob (2003), a CD produced at Warumpi Studio compiled from music workshops with the tracks consisting of sounds made by Kintore and Papunya children sampled and sequenced, with children singing in traditional language over the beats. Marc built a solar powered recording studio in Melbourne in 2006/07, and began a solo project in 2008 releasing As the Market Crashed in 2009 <www.monkeymarc.com>. In 2010, Monkey Marc released "Rock Hop" featuring raps by Kevin Buzzacott (aka MC Buzz Wappa). Donations for downloading this track in support of Buzzacott can be made at: $<$ monkeymarc.bandcamp.com/track/rok-hop-by-buzz-wapper-2?auto=mp3-320 $>$ Also in recent years, Izzy Brown began working in Kenya, the results of which can be seen in the video for the song "Bowdown No Way":

<www.youtube.com/watch?v=fFt9V7Lzqg0>

Mark Peckham, interview with the author, Fungaia Festival, southern Tasmania, 14 February 2004. 